\title{
Self-Selection Bias In On-Line Accounting Courses: Student Characteristics
}

Thomas T. Amlie, (E-mail: amliet@sunyit.edu), State University of New York Institute of Technology

\begin{abstract}
Over the past several years one of my responsibilities as a faculty member of the State University of New York Institute of Technology has been to teach both graduate and undergraduate classes over the internet via the SUNY Learning Network (SLN). Although the work load for a faculty member teaching an on-line course can be substantial, there is evidence that there are unexpected rewards in terms of the caliber of the students who takes such courses. Although the characteristics of the students comprising the initial enrollment of the class mirror those of standard "in-person" classes, there seems to be substantial initial attrition among those students who are less motivated to devote the necessary time to the study of the material. Additionally, the additional responsibility for "active learning" on the part of students appears to motivate many students to a higher level of effort.
\end{abstract}

This paper provides evidence via ex-post and a-priori surveys, as well as through an analysis of the students' final grades, that there is a self-selection bias among students that can lead to an overall increase in the caliber of the on-line class relative to the conventional on-campus class.

\subsection{Introduction}

0 ver the past several years one of my responsibilities as a faculty member of the State University of New York Institute of Technology has been to teach both graduate and undergraduate accounting courses over the internet via the SUNY Learning Network (SLN). The courses which I have taught through the SLN system include Managerial Accounting (the second course in the two-course introductory accounting sequence), Cost Accounting, Advanced Managerial Accounting (a cross listed graduate/undergraduate class), Fund Accounting (graduate), and Accounting for Managers (an introductory accounting course for graduate students). My duties each semester always include both conventional in-person/on-campus courses as well as one or more on-line courses. As I have gained more experience in the on-line course environment I have made some observations regarding the nature of the students who take and complete on-line courses, as well as observations regarding the degree of diligence of on-line students versus students in a conventional classroom setting.

In order to make comparisons between student performance in on-line and in-person classes, I will restrict my analysis to those courses which I offer both on-line and in-person. These courses are Managerial Accounting and Cost Accounting. My other on-line course offerings do not have a corresponding in-person section, so it is not possible to make any comparisons between an on-line section and an in-person section. However, many more subjective observations regarding the students in these "on-line only" courses may be relevant to the discussion as ancillary points.

\subsection{On-line courses in general}

As is the case with conventional classes, the degree of value of an on-line course, and the workload imposed upon students, is completely under the control of the faculty member. In fact, the distinction between a "good" and a "bad" on-line course is probably substantially greater than the distinction between a "good" and a

Readers with comments or questions are encouraged to contact the author via email. 
"bad" on-campus course. I have seen instances of, and have heard reports from students of, on-line courses where the instructor's contribution was often limited to instructions to read a particular chapter, and the students were evaluated largely on the basis of multiple-choice evaluation instruments. At the other extreme are courses where, in addition to instructions to read given sections of the text, the instructor also includes voluminous lecture notes which he or she has prepared, and the students are evaluated based upon their performance on problem- or essay-oriented questions rather than objective multiple-choice questions. Clearly, such extreme variation in the nature of the online courses makes any overall analysis of on-line courses difficult.

When I was first asked to design and administer an on-line course, I had two main concerns which I felt I had to address in the design of my course. First, since the examinations/evaluations are unproctored there needed to be some means of either discouraging collusion among students or enabling collusion to be more readily detected. Secondly, there are valid concerns regarding "selective learning". In a standard in-person class, examinations are essentially a sort of sampling procedure. If students are responsible for 50 points of knowledge, an examination covering 10 or 15 (random) points of knowledge should ensure that students study all of the materials. Since examinations or other assignments in an on-line class are essentially untimed, open book/open note in format, there is a concern that the student will only learn those points of knowledge necessary to complete the assignment.

The only viable solution which I found to address these two problems was to give exhaustive assignments to students. My on-line courses are segmented into two-week "modules", and each module contains written assignments which exhaustively test on all of the materials covered during that module. Such an approach clearly addresses the "selective learning" problem. Additionally, I believe that it also addresses concerns about potential academic honesty problems; students would probably be hard-pressed to find someone to do such substantial amounts of work for them on a regular basis, and if students collude on the assignments (i.e., turn in substantially similar work) it seems to be fairly easy to detect.

Clearly, the on-line courses which I offer involve a substantial degree of work on the part of both myself and the students. What has been interesting has been the degree to which students have either "stepped up to the plate" and done the required work or dropped the course soon after realizing the nature of the workload.

\subsection{Initial student enrollments}

Student enrollments in the on-line sections of the courses in question have historically been substantially higher than enrollments in the on-campus sections. Data on initial enrollment levels is presented in table 1.

TABLE 1:

\begin{tabular}{|l|c|c|}
\hline Course & \# Of Sections in Sample & Initial enrollment of all sections combined \\
\hline Managerial Accounting & 1 on-line & 30 in on-line section \\
& 1 on-campus & 24 in on-campus section \\
\hline Cost Accounting & 2 on-line & 50 in on-line sections (combined) \\
& 2 on-campus & 18 in on-campus sections (combined) \\
\hline
\end{tabular}

The enrollments in the on-line sections seem to be comprised of three groups of students:

1. Students from our own campus who are taking the course on-line because that is the only way it is being offered in the current semester;

2. Students from other institutions (either State University of New York (SUNY) campuses or non-SUNY institutions) who are taking it either out of curiosity or because of scheduling constraints or conflicts at their home campus; and

3. Students who believe that an on-line course will be less rigorous than an on-campus course. These students believe that the on-line course will be an "easy A". 
Since early in my teaching career I have always collected academic background information on my students. During the first week of classes students are asked to fill out $3 \times 5$ index cards with their names, contact information (e.g., address/phone/e-mail), their major area of study, previous accounting classes, and grade point average (G.P.A.). These index cards become the record-keeping device for recording grades on quizzes, examinations, and other assignments, while the academic background information provides me with insights regarding the preparation level of the students in the class. As I moved into on-line teaching, I continued to ask students to provide me with this information. It is the information provided via these mechanisms which serves as the basis for the discussion to follow.

There is bound to be some reporting bias in the information students provide regarding their grade point average. Some students may not be aware of their exact GPA; some may inflate the figure in an effort to appear to be a better student, while others may understate the figure in an effort to get me to lower my performance expectations. The only way to avoid this problem would be to examine the students' official records, which would raise some privacy concerns.

Summary information regarding the grade point averages of students initially enrolled in the classes in question is presented in table 2. The data for the on-line students is incomplete in that some students drop the course before submitting the information. Unlike an on-campus class, where the instructor can take a few moments on the first day of class to ensure that all students provide the requested information, the on-line students provide this information at their leisure. There are invariably several students who register for an on-line course and then drop the course before submitting any of the requested information. These transitory students are not included in any of the analysis which follows.

TABLE 2

\begin{tabular}{|l|c|c|c|}
\hline & \# Of Students & Mean GPA & Standard Deviation \\
\hline Managerial Accounting on-campus & 24 & 2.887 & 0.5676 \\
\hline Managerial Accounting on-line & 30 & 2.798 & 0.6029 \\
\hline Cost Accounting on-campus & 18 & 2.906 & 0.5344 \\
\hline Cost Accounting on-line & 50 & 2.812 & 0.5287 \\
\hline
\end{tabular}

The mean grade point averages of the students initially enrolled do not differ significantly between the online and on-campus courses.

\subsection{Self-selection bias and student performance}

As is noted in the above table, there is no significant difference in the apparent quality of the students in the on-line and on-campus classes. The differences in the students enrolled in each type of class start to become apparent after the class commences.

In an on-campus class, some students seem to rely almost solely on the course materials as delivered in the instructor's lectures. Many of these students can "get by" in this manner, struggling to earn a passing grade while only occasionally (if ever) referring to the materials provided in the text or other readings. When examinations or quizzes are given, students who adopt such a strategy can often secure a marginally satisfactory performance based upon the knowledge they gained as a "passive learner". Such passive learning is limited to the students' recall of the instructor's verbal lectures. I would assume that virtually all faculty members have experience with these types of students. These students teeter on the edge of failure for the entire semester, making the decision to drop the class at the lost possible moment if it appears that their strategy will not work.

Students who are prone to adopt this strategy cannot do so in an on-line class. The only means on-line students have to understand the course subject matter is through a thorough and careful reading of the text and related materials. As students come to the realization that their passive learning strategy will not succeed in this environment, they either drop the course or alter their strategy. 


\subsection{Attrition in on-line courses}

My experience has been that there is a greater level of attrition, sooner in the course, in an on-line course than there is in an on-campus course. In on-campus courses which I teach attrition generally runs about 5\% to $10 \%$ per semester; out of a class of 20 students I expect 1 or 2 to drop over the course of the semester. Additionally, this attrition generally takes place rather late in the course. Most of the "dropping" activity occurs just before the school's deadline for dropping with or without a "W" being recorded on the students' transcript.

In an on-line course, the attrition rate is generally higher (15\% to $20 \%)$ and this attrition generally takes place within a few weeks of the start of the semester. Again, in the on-line courses which I teach I require students to submit lengthy assignments every two weeks. Before the end of the first two-week "module" many students elect to drop the course. Other students straggle on, requesting time extensions for submissions, only to drop within the following week or two. Attrition beyond the first 2 or 3 weeks of the course is almost nonexistent. The attrition figures presented below slightly understate the actual attrition in the on-line classes. Each semester there is uaually at least one student who ceases to log on to the course web-site, and yet does not officially drop the class through the University registrar's office.

Table 3 presents the attrition rates for the courses under discussion here. Unfortunately, reliable data relating to the timing of attrition is not available. Students often cease attending classes well before they go through the official process of "dropping" the course.

TABLE 3

\begin{tabular}{|l|c|c|c|c|}
\hline & $\begin{array}{l}\text { Initial \# of } \\
\text { students }\end{array}$ & $\begin{array}{l}\text { Final number } \\
\text { of students }\end{array}$ & Attrition & $\begin{array}{l}\text { Attrition } \\
\text { rate }\end{array}$ \\
\hline $\begin{array}{l}\text { Managerial Accounting on- } \\
\text { campus }\end{array}$ & 24 & 22 & 2 & $9 \%$ \\
\hline Managerial Accounting on-line & 30 & 25 & 5 & $16.67 \%$ \\
\hline Cost Accounting on-campus & 18 & 17 & 1 & $5.56 \%$ \\
\hline Cost Accounting on-line & 50 & 41 & 9 & $18 \%$ \\
\hline
\end{tabular}

I do not attribute the different attrition rates to any differences in the inherent intellectual abilities of the students. Instead, I view it as a signal of the students' willingness or unwillingness to shoulder the burden for their learning. I have met very very few students whom I believed did not have the intellectual capacity to master the course material.

When the grade point averages of the students who remain registered in the classes are compared, it is apparent that it is generally the lower-performing students who drop the on-line courses. Although the mean GPA figures are still not significantly different, there is a definite pattern to the change in student demographics. The "before" and "after" average grade point averages are presented in table 4.

TABLE 4:

\begin{tabular}{|l|c|c|c|}
\hline & Initial Mean GPA & Post-Attrition Mean GPA & Difference \\
\hline Managerial Accounting on-campus & 2.887 & 2.907 & +0.02 \\
\hline Managerial Accounting on-line & 2.798 & 2.954 & +0.156 \\
\hline Cost Accounting on-campus & 2.906 & 2.929 & +0.023 \\
\hline Cost Accounting on-line & 2.812 & 2.933 & +0.121 \\
\hline
\end{tabular}

As can be noted from the table above, there was a substantial difference between the effect on average GPA of student attrition when comparing the on-line and on-campus sections of these two courses. Part of this, of course, 
is due to the relatively low attrition levels in the on-line courses. In the case of the on-campus cost accounting class, the loss of one student out of 18 cannot affect the average GPA of the class in a significant manner.

\subsection{Performance of remaining students}

The aspect of on-line teaching which has been the most surprising (and the most pleasing) is the degree to which on-line students have been willing and able to perform the tasks assigned to them. Since I use different evaluation metrics in my on-campus versus on-line courses, it is difficult to make any unassailable statements regarding relative student performance in the two environments. Students in on-campus courses are evaluated based on 3 examinations plus quizzes, which are always administered as timed, closed book/closed note activities. Students in on-line courses are evaluated based on 7 equally-weighted end-of-module assignments, their contributions to course discussions, and a final exam. These activities are essentially untimed (the students have 2 weeks in which to perform the work) and are open book/open note.

The final grade distributions of the course sunder discussion are presented in table 5.

TABLE 5:

\begin{tabular}{|l|c|c|c|c|c|}
\hline & "A" & "B" & "C" & "D" & "F" \\
\hline Managerial on-campus & $0 \%$ & $9 \%$ & $50 \%$ & $27 \%$ & $14 \%$ \\
\hline Managerial on-line & $43 \%$ & $21 \%$ & $21 \%$ & $7 \%$ & $7 \%$ \\
\hline Difference (on-line less on-campus) & $+43 \%$ & $+12 \%$ & $-29 \%$ & $-20 \%$ & $-50 \%$ \\
\hline & & & & & \\
\hline Cost on-campus & $12 \%$ & $35 \%$ & $23 \%$ & $18 \%$ & $12 \%$ \\
\hline Cost on-line & $40 \%$ & $35 \%$ & $10 \%$ & $5 \%$ & $10 \%$ \\
\hline Difference (on-line less on-campus) & $+28 \%$ & N/C & $-13 \%$ & $-13 \%$ & $-2 \%$ \\
\hline
\end{tabular}

Notes:

1. The "Cost on-line" grades are based on one section of Cost Accounting on-line since the second section of this course is currently in progess.

2. The proportion of "F" grades in the on-line cost accounting class would seem to speak against my points regarding student performance in on-line classes. Of the 5 " $\mathrm{F}$ " grades I've given in these on line classes, only one was "earned"; that is, the student attempted to complete the course. The others are attributable to students who dropped the course on a de-facto basis but did not drop the course with the University registrar in time to avoid taking a grade in the course.

Clearly, a compelling argument against the data provided in table 5 could be made based upon the fact that the in-class examinations and quizzes are timed, closed book/closed note while the on-line evaluations are not. I can offer only anecdotal evidence to suggest that this might not be a substantial factor.

In the never-ending quest to get students to study and prepare more, I've resorted to handing out and then collecting assignments comprised of examination questions from previous semesters. These assignments are given a moderate weight in the determination of the students' final grades, and students generally have from one and one half to two weeks to complete them. These same packets of questions are often distributed to the on-line students as part of their on-going workload. Even though the conditions under which the students are required to complete the work are identical, the on-line students' performance is generally substantially better than the in-class students' performances. Again, I attribute the difference in the apparent performance of the on-line students to their recognition of the fact that it is their responsibility to actively study the course materials, rather than attempt to learn the materials via passively watching and listening to the instructor. 
Notes 